\title{
GEOLOGY OF THE SLEETMUTE A-5, A-6, B-5, AND B-6 QUADRANGLES, SOUTHWESTERN ALASKA
}

by

John Decker, R.R. Reifenstuhl, M.S. Robinson, C.F. Waythomas, and J.G. Clough

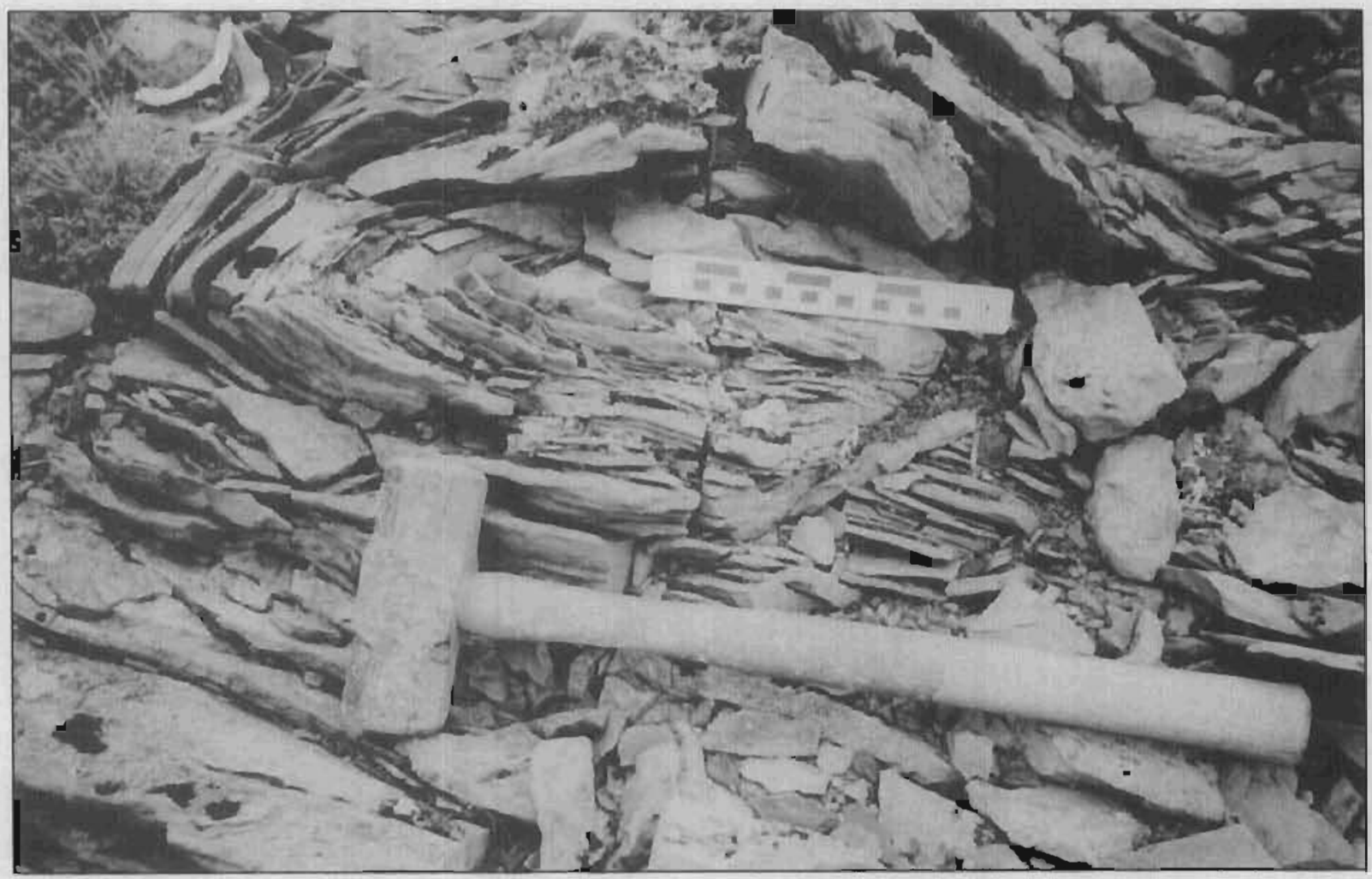

Professional Report 99

1995

Published by

State of Alaska

Department of Natural Resources

DIVISION OF GEOLOGICAL \& GEOPHYSICAL SURVEYS

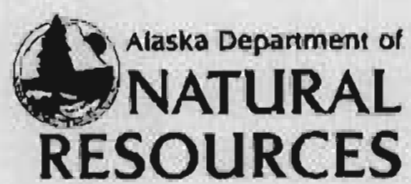




\section{GEOLOGY OF THE SLEETMUTE A-5, A-6, B-5, AND B-6 QUADRANGLES, SOUTHWESTERN ALASKA}

by

John Decker, R.R. Reifenstuhl, M.S. Robinson, C.F. Waythomas, and J.G. Clough

Professional Report 99

Division of Geological \& Geophysical Surveys

Cover photo: Northwest-yergent isocline of very fine-grained sandstone of the Lowert?) and Upper Cretaceous Kuskokwim Group. The oulcrop of mediumbedded sandstone is 1.5 miles west of Kiokluk Lake in the Sleetmule B-6 Quadrangle (map unit $K \mathrm{~km})$. The hammer handle in the photo is $46 \mathrm{~cm}$ Fairbanks, Alaska long. Photo by R.R. Reifenstuhl. 


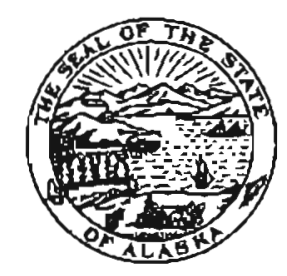

STATE OF ALASKA

Tony Knowles, Governor

DEPARTMENT OF NATURAL RESOURCES

John Shively, Commissioner

\title{
DIVISION OF GEOLOGICAL \& GEOPHYSICAL SURVEYS
}

Milton A. Wiltse, Acting Director and State Geologist

Division of Geological \& Geophysical Surveys publications may be inspected at the following locations. Address mail orders to the Fairbanks office.

Alaska Division of Goological

\& Geophysical Surveys

794 University Avenue, Suite 200

Fairbanks, Alaska 99709-3645

Elmer E. Rasmuson Library

University of Alaska Fairbanks

Fairbanks, Alaska 99775-1005
University of Alaska Anchorage Library 3211 Providence Drive

Anchorage, Alaska 99508

Alaska Resource Library

$222 \mathrm{~W} .7$ th Avenue

Anchorage, Alaska 99513-7589

\begin{abstract}
Alaska State Library
State Office Building, 8th Floor

333 Willoughby A venue

Juneau, Alaska 998 I I-0571
\end{abstract}

This publication released by the Division of Geological \& Geophysical Surveys, text was produced and printed in Fairbanks, Alaska by Graphics North and maps were printed in Colorado Springs, Colorado by Pikes Peak Lithographing Co., at a cost of $\$ 9.50$ per copy. Publication is required by Alaska Statute 41, "to determine the potential of Alaskan land for production of metals, minerals, fuels, and geothermal resources; the location and supplies of groundwater and construction materials; the potential geologic hazards to buildings, roads, bridges, and other installations and structures; and shall conduct such other surveys and investigations as will advance knowledge of the geology of Alaska." 


\section{CONTENTS}

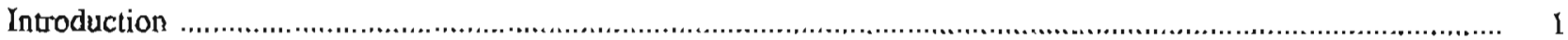

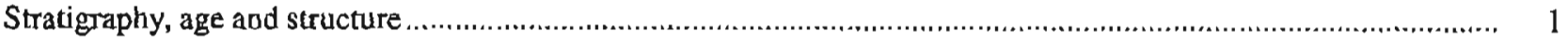

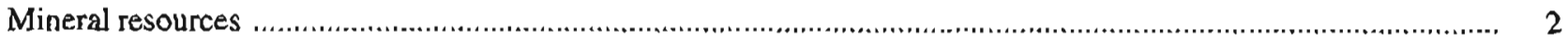

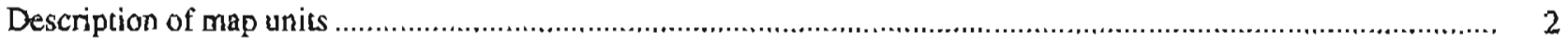

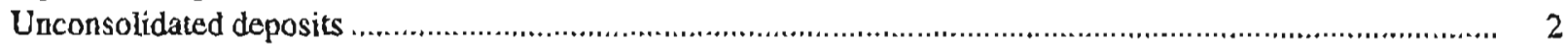

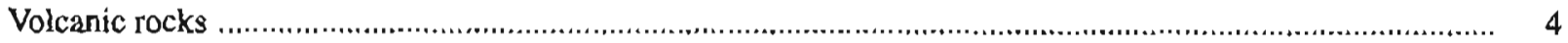

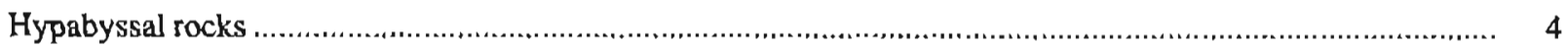

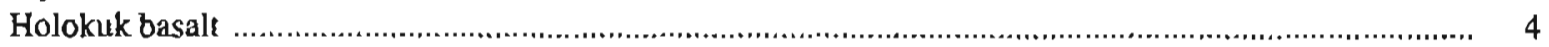

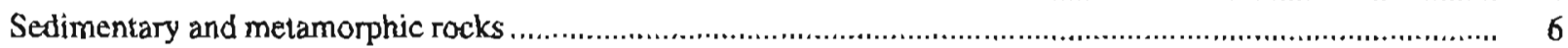

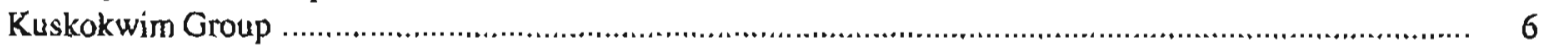

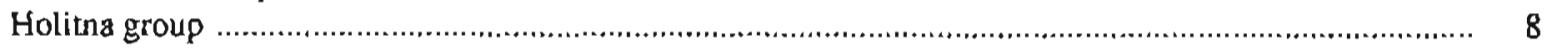

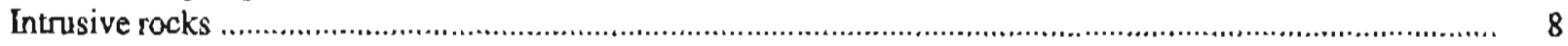

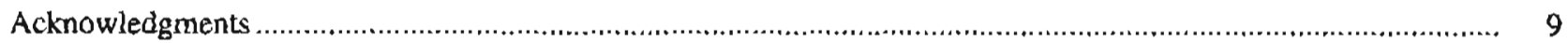

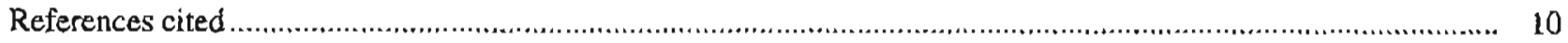

\section{FIGURE}

Figure 1. Map showing paleocurrent data for the Sleetmute A-5, A-6, B-5, and B-6 Quadrangles ................. 10

TABLES

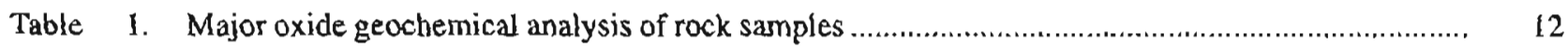

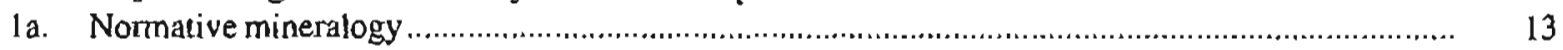

2. Trace element geochemical analyses of rock samples ........................................................... 15

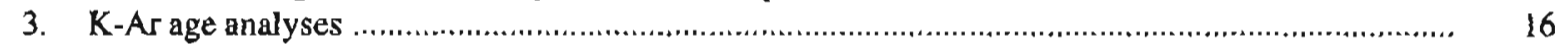

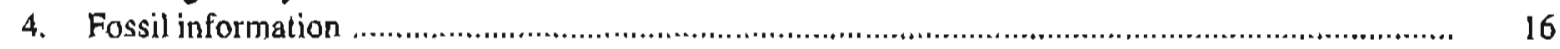

\section{MAPS \\ [in pocket]}

Sheet 1. Geologic map of the Sieetmute A-5, A-6, B-5, and B-6 Quadrangles, southwestern Alaska

2. Stratigraphic sections in the Sleetmute A-6 and B-6 Quadrangles, southwestern Alaska 


\title{
GEOLOGY OF THE SLEETMUTE A-5, A-6, B-5, AND B-6 QUADRANGLES, SOUTHWESTERN ALASKA
}

\author{
by \\ John Decker,' R.R. Reifenstuhl, ${ }^{2}$ M.S. Robinson, ${ }^{3}$ C.F. Waythomas, ${ }^{4}$ and J.G. Clough ${ }^{2}$
}

\section{INTRODUCTION}

The Sleetmute A-5, A-6, B-5, and B-6 Quradrangles are located $450 \mathrm{~km}(280 \mathrm{mi})$ west of Anchorage in the Kuskokwim Mountains of southwestemAlaska. Elevation in the map area ranges from about $1,300 \mathrm{~m}(4,265 \mathrm{ft})$ in the pluton-cored Kiokluk and Chuilnuk Mountains to $100 \mathrm{~m}$ (328 ft) along the Holitna River and Chineekiuk Creek. Except for the glaciated peaks of the Chuilnuk and Kiokluk Mountains, the physiography of the area is dominated by rounded, tundra-covered hills of low to moderate relief.

Geologic mapping utilized 1:40,000-scale topographic base maps, 1;63,360-scale aerial photographs, and field notes and maps from unpublished U.S. Geological Survey field studies. A reconnaissance study by Cady and others (1955) included the quadrangles mapped in this report.

Preliminary 1:40,000-scale geologic maps of the Sleetmute A-6, B-5, and B-6 Quadrangles have been published, respectively, by Decker, Robinson, Murphy, Reifenstuhl, and Albanese (1984), Reifenstuhl, Robinson, Smith. Albanese, and Allegro (1984), and Robinson and others (1984). Rock, pan-concentrate, and streamsediment geochemistry maps of the Sleetmute A-6, B-5, and B-6 Quadrangles were compiled by Robinson (1984a, b, c respectively). Compilations of previously unpublished data, mainly from U.S. Geological Survey field studies, are available in Alaska Division of Geological \& Geophysical Surveys Public-data File maps (Decker, Reifenstuhl, and Coonrad, 1984; Reifenstuhl, Decker. Murphy, and Coonrad, 1984; and Murphy and others, 1984).

\section{STRATIGRAPHY, AGE AND STRUCTURE}

The oldest rock unit in the region is the Holitna Group of Cady and others (1955). These authors reported Silurian and Devonian fossils, but inferred that Ordovician strata may also be present. More recent field iovestigations bave shown that strata as old as Cambrian and as young

\footnotetext{
'ARCO Alaska, Inc., P.O. Box 100360, Anchorage, Alaska 99510-0360.

${ }^{2}$ Alagka Division of Geological \& Googhysical Surveys, 794 University Avenue, Suite 200, Fairbanks, Alaska 99709-3645.

${ }^{3}$ Wrangle Shipyard Inc., Box 1348, Wrangle, Alaska 99929.

${ }^{4}$ U.S. Geological Survey, Water Resources Division, Grace Hatl, 4230

University Drive, Suite 200, Anchorage, Alaska 99508.
}

as Triassic are also present within their Holitna Group. The oldest strata recognized in the unit, based on regional correlation with the Lone Mountain area of the McGrath Quadrangle, are of probable Late Proterozoic age (R.B. Blodgett, written commun., 1994). Adrain and others (in press) have suggested that the designation "Holitna Group" be ultimately abandoned, because it is too broadly defined. We agree with this, and use Holitna group as an informal unit designation within our report area.

Most of the area is underlain by the Kuskokwim Group, a $>12-\mathrm{km}$-thick $(39,370 \mathrm{ft})$ marine turbidite sequence of thick- to medium-bedded sandstone and shale. The age of the Kuskokwim Group has been generally considered Early Cretaceous and Late Cretaceous (Albian to Coniacian) (Moore and Wallace, 1985; Decker and others, 1994). The inclusion, by these authors, of the Early Cretaceous (Albian) age-range is based on the rare occurrence of one species of arenaceous foraminifera of probable Albian age from the Mulchatna River area. This occurrence was reported in an in-house ARCO Alaska fossil report (Moore and Wallace, 1985). Numerous published reports on Kuskokwim Group macrofossils indicate a Late Cretaceous (Cenomanian to Santonian) age and none reports ages other than Late Cretaceous (Cady and others, 1955; Elder and Box, 1992; Box and Elder, 1992; Elder and Miller, 1991). Consequently, we will refer to the Kuskokwim Group age as Early(?) and Late Cretaceous (Albian(?) to Santonian).

A far less extensive rock unit, superficially resembling the Kuskokwim Group, is the Inoceramusbearing calcareous sandstone, siltstone, and shale of Cretaceous to Jurassic(?) age. Contacts between the calcareous deposits and otber bedrock units are covered by surficial deposits.

The Holokuk Basalt (Cady and ochers, 1955) coosists of calc-alkalic volcanic rocks (table 1) that unconformably overlie the Kuskokwim Group and range in composition from basaltic andesite to rhyolite, K-Ar ages range from 64.3 to $74.5 \mathrm{Ma}$. This formation is $>1 \mathrm{~km}$ $(3,280 \mathrm{ft})$ thick and consists of subaerial flows and interlayered agglomerate, tuff breccia, basalt-matrix conglomerate, and lahar deposits; is is spatially and chronologically associated with nearby plutonic rocks. Low initial $\mathrm{Sr}^{87} / \mathrm{Sr}^{86}$ ratios in the rhyolitic rocks preclude involvement of radiogenic continental crust in their genesis (table 2). 
Professional Report 99

Two granodiorite stocks of latest Cretaceous age (mean of $\mathrm{K}$-Ar ages $=68.2 \mathrm{Ma}$; table 3 ) occur in the Chuilnuk and Kiokluk Mountains. The Holokuk Basalt is locally homfelsed in the western Kiokluk Mountains by one of these plutons. Latest Cretaceous to earliest Tertiary volcano-plutonic complexes of similar size, age. and composition are common throughout southwestern Alaska (Bundizen and Laird, 1982; Bundzen and Laird, 1983; Bundtzen and Laird, 1992; Bundtzen and others, 1992; Decker, 1994; Miller and Bundtzen, 1994; Moll-Stalcup. 1994).

Hypabyssal rocks include mafic to felsic dikes and small stocks of Tertiary and Cretaceous age. The youngest volcanic rock is columnar-jointed olivine basak, dated at $38 \mathrm{Ma}$ (sample 20, table 3).

Quaternary surficial deposits, subdivided into 24 units, define four glacial advances: (1) Oskawalik Creek drift (early Pleistocene); (2) Chuilnuk drift (middle late Pleistocene); (3) Buckstock drift (late Pleistocene); and (4) Kiokluk peak drift (Holocene). The chronology of these surficial deposits was determined on the basis of relative dating.

The Kuskokwim Group is variably deforned by overturned and isoclinal folds, broad open folds, and local polyphase deformation, Layered Holokuk Basalt deposits were gently folded after $65 \mathrm{Ma}$. The Boss Creek and Holitna faults, which offset late Pleistocene deposits, are splays of the Denali-Farewell fault system and have uncertain Cretaceous and Tertiary histories.

\section{MINERAL RESOURCES}

Dickite-bearing altered dikes such as those in the andesite dikes map unit (Kim) are commonly associated with lode occurrences of cinnabar and antimony in the lower Kuskokwim region (Sainsbury and MacKevett, 1965).

Rocks of the lower Kuskokwim River region host placer deposits of gold and tungsten, vein deposits of mercury, antimony and other base and precious metals, and greisen deposits containing tin and other base and precious metals.

Gold and scheelite occur in placer deposits along Fortyseven Creek (lat $61^{\circ} 02^{\prime} 40^{\prime \prime}$ N.. long $158^{\circ} 09^{\prime} \mathrm{W}$.) and originate from a series of mineralized quartz veins that cut hornfelsed Kuskokwim Group where Fortyseven Creek heads. The hornfelsed sedimentary rocks weather a distinctive brown and contain secondary biotite; they were probably produced by intrusion of a small rhyolite plug near the head of Fortyseven Creek. The quartz veins are typical hydrothermal vein deposits, ranging in width from a few centimeters to more than a meter, and can be traced discontinuously for tens of meters along strike; they contain minor calcite and white mica, which yielded a K-Ar age of $60.9 \pm 1.8 \mathrm{Ma}$. (sample 21, table 3). Chlorite and sericite selvages border most of the veins. Ore minerals in the veins include gold, scheelite, wolframite, arsenopyrite, pyrite, jamesonite, stibnite, argentite, and rare gold-silver tellurides. Gangue minerals include quartz, carbonate, white mica, tourmaiine, and sericite. Gold and scheelite have been recovered from placers (Cobb, 1976), but there is no record of production.

Several mercury and antimony deposits are koown in the map area. The Mountain Top deposit (lat $61^{\circ} 23^{\prime} 47^{\prime \prime} \mathrm{N}_{\text {., }}$ long $157^{\circ} 58^{\prime} 23^{\prime \prime} \mathrm{W}$.), the best exposed of the mercury deposits, is located about $16 \mathrm{~km}$ (9.9 mi) north of Kiokluk Lake and has produced an unknown amount of mercury; visible reserves are estimated at 200 flasks (Cobb, 1976). The deposit is hosted in highly sheared and aitered sedimentary and volcanic rocks. Most of the known mercury and antimony mineralization is localized in probable tectonic breccias near the contacts between brecciated and unbrecciated basaltic andesite. The source of mercury is not known, but some mineralized breccias at Mountain Top may represent vent breccias, and mineralization may originate from hot springs.

Tin occurs in quartz-tourmaline veins and slockworks in the Chuilnuk and Kiokluk plutons and in homfelsed Kuskokwim Group sedimentary rocks near pluton contacts.

All known mineralized zones in the area appear to have downstream or downslope geachemical signatures. Stream-sediment geochemistry may therefore be useful in delineating new mineralized areas.

\section{DESCRIPTION OF MAP UNITS}

\section{UNCONSOLIDATED DEPOSITS}

Qa MODERN FLOOD-PLAIN ALLUVIUMModerately to well-sorted cobble and pebble gravel, sand, and overbank silt along the channels of modern streams and rivers. Abundant organic debris locally and good primary stratification. May be mantled by thin $(<\mathrm{cm})$ colluvium or loess or both

Qaf ALLUVIAL-FAN DEPOSITS-Variously sorted, weakly stratified cobble and pebble gravel in a sand and silt matrix. Associated with cone- or fan-shaped alluvial deposits along the bases of mountain fronts and valley slopes. May contain lenses of angular colluvial gravel

Qp PEAT, PEATY SILT, AND OTHER PALUDAL DEPOSITS - Generally thick accumulations of peat and organic silt in fers and swamps; locally interbedded with loess; usually capping fluvial sediments. Includes palsas, fens, and string fens 
QC UNDIFFERENTIATED COLLUVIAL DEPOSITS-Angular, poorly sorted, unstratified gravel in a silty matrix on slopes of $45^{\circ}$ or less. Derived principally from frost-shattered bedrock. May contain solifluction deposits and minor alluvium

Qcs SOLIFLUCTION DEPOSITS-Poorly sorted, angular gravel in a silty matrix. Associated with lobate or tongue-like microrelief forms on colluvial slopes

QCX FINE-GRAINED COLLUVIUM-Retransported silt or muck, locally interbedded with sand and gravel lenses, mainly where it overlies alluvium on lower slopes and valley bottoms

Qct TALUS-Frost-rived, blocky rock rubble forming cones, fans, and aprons along base of steep mountain slopes. Includes avalancheboulder tongues, boulder trains and runs, and rockfall debris

Qcl LANDSLIDE DEPOSITS-Hummocky, heterogeneous to chaotic debris deposited by slope failures, including slump, slides, and slips

Qd RBTRANSPORTED DRIFT-Unsorted, unstratified silty gravel with variable amounts of sand and boulders on glaciated valley slopes; gradational with undisturbed drift

Qrg ROCK-GLACIER DEPOSITS-Lobate or tongue-shaped accumulations of bouldery rubble below talus and scree slopes, showing evidence such as multiple, crescentic ridges, of downslope movement

Qd UNDIFFERENTIATED GLACIAL DEPOSITS-Mixtures of till, outwash, and minor colluviated drift or other glacial diamicton not readily separated. Poorly sorted, generally unstratified, gravelly sediment with a sand to silt matrix

$\mathrm{Qd}_{4}$ GLACIAL DRIFT OP KJOKLUK PBAK ADVANCE-Poorly sorted bouldery drift in highest. north-facing cirque of Kiokluk Mountains

Qd GLACIAL DRIFT OF BUCKSTOCK GLAClATION-Diamicton associated with unmodified knob-and-kettle moraines. Poorly sorted bouldery gravels to well-sorted sandy gravel. May include some outwash gravel, flow till, and loess
$\mathrm{Qd}_{2}$ GLACIAL DRIFT OF CHUILNUK GLACIA. TION-Diamicton of subdued morairal deposits and outwash, forming isolated remnants close to modern valley floors. Poorly to moderately sorted silty gravel with variable amounts of sand and boulders; moraines exhibit local huramocky topography with kettles

Qd, GLACIAL DRIFT OF OSKAWALIK CREEK GLACIATION-Diamicton of very subdued drift bodies partially capping ridges and knolls; includes minor outwash, retransported drift and solifluction deposits. Composed of poorly sorted silty gravel, localiy frozen at depths of $2-3 \mathrm{~m}$

QcC BLANKET COLLUVIUM-Blocky rock rubble with variable amounts of fine-grained material as blankets. Includes stone stripes, solifluction debris, stone-banked terraces, and protalus lobes

Qld LACUSTRINE DELTAIC DEPOSITS-Wellsorted sands and silts deposited in standing bodies of water

Qf UNDIFFERENTIATED FLUVIAL DEPOSITS-Moderately to well-sorted cobble and pebble gravel, sand, and overbank silt. Commonly with well-developed primary fluvial sedimentary structures, and associated with inactive flood plains and stream teraces

Qcf UNDIPPERENTTATED COLLUVIUM AND ALLUVIUM-Complexly mixed colluvial and fluvial deposits forming debris-rich fans. on most mountain slopes or at mouth of steep bedrock walls, couliers, and valleys. Consists of poorly stratified. unsorted gravel to silt, often with crude clast imbrication and bouldery zones; includes deposits of mudflows, debris flows, slushflows, snow avalanches, and lloods

Qdo UNDIFPERENTIATED OUTWASH-Wellsorted cobble to small-boulder gravel, usually exhibiting obvious primary stratification. Contains rounded to subrounded clasts. Locally capped by $1-2 \mathrm{~m}$ of eolian silt or sand or both. Age uncertain

$\mathrm{QdO}_{3}$ OUTWASH OP BUCKSTOCK GLACIATION-Well-sorted, stratified, cobble and pebble gravel and sand; locally mantled by $1-2 \mathrm{~m}$ of eolian silt. Outwash valley trains or outwash 
heads related to Buckstock terminal moraines and ice limits

Qdo 2 OUTWASH OF CHUMNUK GLACIATIONModerately to well-sorted, stratified, cobble and small-boulder gravel; locally mantled by $1-2 \mathrm{~m}$ of eolian sediment, colluvium or both. Most outwash valley trains or outwash heads related to Chuilnuk terminal moraines and ice limits

Qdo, OUTWASH OF OSKAWALIK CREEK GLACIATION-Moderately well sorted cobble gravel forming terrace remnants not directly traceable to equivalent terminal moraines. Probable remnants of extensive valley-fill deposits that have been buried, redistributed, and dissected

Qat UNDIFFERENTIATED STREAM-TERRACE DEPOSITS-Cobble to pebble gravel and sand, typically well sorted and stratified in stream tersaces $>2 \mathrm{~m}$ high. Commonly mantled by eolian silt

\section{VOLCANIC ROCKS}

Tvb COLUMNAR BASALT-Rubble of fresh olivine basalt exposed locally on densely vegetated hillside $10 \mathrm{~km}$ northeast of Fortyseven Creek. One whole-rock sample yielded K-Ar age of $38.2 \pm 1.1 \mathrm{Ma}$. (table 3)

$\mathrm{TVr}_{3}$ GRAY RHYOLITE-Light- to mediumagray and buff, fine-grained, well-layered to massive rhyolite and rhyolite tuff breccia. Rhyolite contains irregular clots of hematite $105 \mathrm{~mm}$ diam; weathered rhyolite is distinctively hematite-stained and spotted; exact nature of contact with under\}ying black rhyolize unic $\left(\operatorname{Tvr}_{2}\right)$ is unclear; one sample yielded K-Ar age of 43.8 Ma (table 3). Intermixed with hematite-spotted، gray rhyolite are zones of light-gray thyolite tuff breccia composed of angular and subangular clasts of shale, sandstone, and volcanic rocks in a very fine grained scoriaceous matrix. Tuff breccia occurs in well-layered sequence near core of volcanic complex

$\mathrm{TVr}_{2}$ BLACK RHYOLITE-Very dark gray to black, fine-grained, porphyritic rhyolite; includes minor basaltic andesite. Rhyolite contains alkali feldspar (sanidine) phenocrysts to $10 \mathrm{~mm}$ long and beta-quartz phenocrysts to $3 \mathrm{~mm}$ diam in a very fine grained, glassy groundmass. Quartz and feldspar fragments are common. Locally contains exotic clasts of shale, sandstone, and rhyolitic to basaltic volcanic rock. Unit locally underlain and cut by thin $(15 \mathrm{~m})$ zones of darkgray to black fragmental volcanic rock composed of shale, sandstone, rhyolite, and basalt clasts in obsidian-like matrix. Unit appears to be locally discordant; may represent dikes or sills

TVr, RHYOLITE-Tan to olive-green, fine-grained, porphyritic rbyolite with abundant quartz phenocrysts to $3 \mathrm{~mm}$ diam and alkali feldspar (sanidine) phenocrysts to $5 \mathrm{~mm}$ long; locally, phenocrysts constitute as much as 20 percent of rock. Rhyolite occurs as several thick $(\sim 30 \mathrm{~m})$ layers which exhibit no perceptible change in composition. The contact between this unit and the overlying black rhyolite ( $T v r_{2}$ ) appears locally conformable. Exact nature of lower contact with basalt is unknown

\section{HYPABYSSAL ROCKS}

\section{Holokuk Basalt}

The Holokuk Basalt was named by Cady and others (1955). It is a gently dipping sequence of predominantly basaltic volcanic rock, containing minor rhyolite, vitric tuff, and breccia, in the western Sleetmute Quadrangle. The formation is at least I km thick and unconformably overlies the Kuskokwim Group. Cady and others (1955) assigned a Tertiary (late Eocene to carly Miocene) age, mainly on the basis of struciural arguments. New radiometric age data, however, suggest that Holokuk volcanism took place between 64.3 and 74.5 Ma, or during latest Cretaceous to very earliest Tertiary time. Whole-rock major-oxide data (table 1) indicate a basaltic andesite to rhyolite compositional range (Peccerillo and Taylor, 1976). Seven samples from the Holokuk Basalt yielded K-Ar ages ranging from 64.3 to $74.5 \mathrm{Ma}$ (mean of $\mathrm{K}$-Ar ages $=70.0 \mathrm{Ma}$; table 3); the Holokuk Basalt is therefore probably correlative with the Upper Cretaceous Iditarod Basall (Cady and others, 1955), and possibly the undated Getmusa Rhyolite Group (Cady and others. 1955) in the northern Sleetmute and southern Iditarod Quadrangles. In the Kiokluk and Chuilnuk Mountains, rocks previously mapped by Cady and others (1955) as the Holokuk Basalt are here subdivided into 10 informal units.

Khap BASALTIC ANDESITE-Dark-gray 10 brown and green, very fine grained, porphyritic basaltic andesite. These rocks contain plagioclase 
phenocrysts to $3 \mathrm{~mm}$ long, clinopyroxene (augite?) to $2 \mathrm{~mm}$ diam, olivine in anhedral masses to $2 \mathrm{~mm}$ diam, and orthopyroxene as sub. hedral grains to $3 \mathrm{~mm}$ long. Olivine and orthopyroxene are altered to serpentine minerals. The basaltic andesite occurs as thick flow(?) units which unconformably overlie rocks of Kuskokwim Group. Six basaltic andesites in the map area yielded $\mathrm{K}$-Ar ages of $64.3,68.3,68.0$, $70.7,70.8$, and $74.5 \mathrm{Ma}$ (mean of $\mathrm{K}$-Ar ages $=$ 69.4 Ma; table 3)

Khlb

INTERLAYERED LAHAR DEPOSITS AND BASALTIC ANDESITE-Grayish-green, browaish-red, dark-green, and black interlayed lahar deposits and basaltic andesite. Basal sequence depositionally overlies Upper Cretaceous Kuskokwim Group and is locally crosscut by Cretaceous andesite dikes (Kim). Basaltic andesite occurs as massive flows and dikes and contains plagioclase, olivine, or pyroxene phenocrysts. Olivine is moderately to higbly astered to serpentine minerals and magnetite. One $\mathrm{K}-\mathrm{Ar}$ whole-rock sample gave a minimum age of $73.2 \pm 2.2 \mathrm{Ma}$ (table 3 ). This unit is $426 \mathrm{~m}$ thick in a measured section $5 \mathrm{~km}$ east of Holokuk Mountain (Reifenstuhl, Robinson, Smith. Albanese, and Allegro, 1984; sheet 2)

RED AND GRAY LAHAR DEPOSITSBrownish-red, matrix supported deposit; locally contains angular to rounded pyroxene basalt clasts from 0.5 to $70 \mathrm{~cm}$ diam. Muddy volcaniclastic matrix locally forms up to 60 percent of the rock. Gray lahar deposit is distinctive grayish green, unstratified, and composed of angular, very poorly sorted mafic volcanic clasts in weakly indurated groundmass. Locally interbedded with graded muddy sandstone and mudstone; individual beds range in thickness from 10 to $80 \mathrm{~cm}$; may be tightly folded; contacts with volcanic rocks are sharp and irregular

Kha RED BASALTIC ANDESITE-Massive, brownish-dark-red basaltic andesite with plagioclase phenocrysts to $4 \mathrm{~mm}$ long in matrix of plagioclase laths $<0.2 \mathrm{~mm}$ long, brown volcanic glass, and chalcedony. Locally, subhedral orthopyroxene is $1.2 \mathrm{~mm}$ long and constitutes up to 8 percent of rock. Occurs above and below red and gray labar deposits unit (Khl)

Khr containing quartz phenocrysts $104 \mathrm{~mm}$ diam, with laminated, swirled, and contorted flow banding

Khf INTERMEDIATETO FELSIC FLOWS, TUFF, AND AGGLOMERATE-Textures and compositions vary greatly within this unit, and only thick, disinct layers can be correlated laterally. Prominent litbologies are: (1) dark-green to gray, platy-weathering, thiniy laminated aphanitic andesite containing aligned plagioclase laths, relict hornblende(?), and minor secondary chlorite with local, small-scale isoclinal flow(?) folds; (2) light-green to medium-gray felsic- to intermediate apbanite; (3) tan-weathering intermediate agglomerate containing subangular, intermediate lithic clasts to $2.5 \mathrm{~cm}$ long, with epidote and calcise along fractures and to 3 percent disserninated pyrite; (4) finely laminated amygdaloidal basalt with secondary calcite and chlorite; and (5) finely laminated, light-green lithic tuff with clasts to $1.5 \mathrm{~cm}$ long, a black matrix, and locally graded bedding. Conformably overlies massive and amygdaloidal basaltic andesite unit (Khaa). Unit is homfelsed by Kiokluk pluton in western Kiokluk Mountains

Khaa MASSIVE AND AMYGDALOIDAL BASALTIC ANDESITE-Sequence of basaltic andesite and andesite flows with thick massive bases and thin amygdaloidal tops. Massive flows are dark-gray, olivine-augite andesites with finegrained trachytic groundmass. Olivine is subhedral, generally $0.2 \mathrm{~mm}$ diam, and constitutes 1 percent of rock. Augite is euhedral to subhedral, $1.5 \mathrm{~mm}$ long, and 2 percent of the rock. Amygdaloidal andesites are gray to black where fresh, and weather to maroon and green. Amygdules are $2.5 \mathrm{~cm}$ long, irregularly shaped, rounded or flattened, commonly lined with concentric chalcedony, and filled with one or more of the following: quartz, calcite, epidote, or chlorite. Amygdaloidal zones range from 0.6 to $8.0 \mathrm{~mm}$ thick; amygdule size increases from base to top. Basalt-matrix conglomerate occurs at the base of the unit and contains subrounded shale and sandstone fragments derived from the underJying Kuskokwim Group. These clastic fragments are up to $2.5 \mathrm{~cm}$ long with little or no evidence of thermal metamorphism. This unit is overlain by the intermediate to felsic fows, tuff, and agglomerate unit (Khf). Unit is hornfelsed by Kiokluk pluton in western Kjokluk Mountains. Unit is $258 \mathrm{~m}$ thick at Peak 3770 and 
consists of at least six basalt flows, each with thick massive base and thin amygdaloidal top (Decker, Robinson, Murphy, Reifenstuhl, and Albanese, 1984; sheet 2)

Khtb TUFF BRECCLA-White to green, felsic to siliceous, aphanitic to sandy-matrix tuff breccia. Local flow banding may be swirled or contorted. Quartz phenocrysts to $4 \mathrm{~mm}$ diam occur locally. Pyrite blebs to $1 \mathrm{~cm}$ diam constitute to 3 percent of rock

Khb FELSITE BRECCIA-White to light-gray, vertically jointed, matrix-supported breccia containing subangular felsite clasts to $0.6 \mathrm{~m}$ diam in a felsite matrix. Locally, north of Peak 3770 , breccia matrix contains to 20 percent green to brown pleochroic courmaline as radiating clusters with individual crystals to several centimeters long. Contact relationships with adjacent units unclear

Khe BASALT-MATRIX CONGLOMERATEBrown-weathering sandstone and shale, pebble to granule conglomerate in a light-green volcanic matrix. Contains subrounded shale and sandstone fragments derived from the underlying Kuskokwim Group. Clasts are up to $2.5 \mathrm{~cm}$ long and indicate only minor thermal metamorphism. In western Kiokluk Mountains, unit is thermally metamorphosed by Kiokluk stock. In the northwest part of map area, this basal unit is mapped as tuff breccia, which contains basalt and shale clasts in a sandy matrix

\section{SEDIMENTARY AND METAMORPHIC ROCKS}

\section{Kuskokwim Group}

The Kuskokwim Group (Cady and others, 1955) consists primarily of marine turbidites and subordinate fluvial and shallow marine strata deposited in an elongate, southwest-trending basin covering over $70,000 \mathrm{~km}^{2}$ in southwestern Alaska. The Kuskokwim Group is thickest $(>12 \mathrm{~km})$ in the central part of the basin between the villages of McGrath and Aniak. Mixed marine and nonmarine sections are relatively thin $(<3 \mathrm{~km})$ and are restricted to basin margins and local basement highs. The Kuskokwim Group is Early(?) and Late Cretaceous (Albian(?) to Santonian) age, on the basis of sparse age-diagnostic megafossil collections ( $<50)$ and a few collections of fossil plants, palynomorphs, and dinoflagellates (table 4; Decker and others, 1994).
The Kuskokwim Group in the Sleetmute A-5, A-6, B-5, and B-6 Quadrangles is poorly exposed; it typically forms low, rolling bills mantled with vegetation and frostshattered bedrock. There are few outcrops where bedding can be determined with certainty and stratigraphic relations observed; some occur along cutbanks of major rivers, in steep gulleys, and in hornfelsed rock adjacent to the Kiokluk and Chuilnuk stocks.

The Kuskokwim Group in and around the Kiokluk and Chuilnuk Mountains consists entirely of marine turbidites, subdivided here into two informal units: medium-bedded sandstone and shale $(\mathrm{Kkm})$, and thickbedded sandstone and shale (Kkt). Bouma (1962) intervals for individual turbidite beds are indicated by subscript: ( $T_{\text {abcde }}$ ). Groups of beds are assigned to facies according to the model of Mutti and Ricci Lucchi (1972): B, C, D, E, F, G. It was not possible to consistently distinguish between shale related to turbidity currents $\left(T_{e}\right)$ and that of normal hemipelagic regime (facies $G$ ). Thin shale beds interbedded with sandstone and siltstone turbidite are referred to arbitrarily as $\mathrm{T}_{\mathrm{e}}$, and thick shaly intervals are assigned to facies $\mathrm{G}$.

Kkm MEDIUM-BEDDED SANDSTONE AND SHALE-Light- to dark-gray, medium- to very fine grained, massive, graded, plane-laminated and crossbedded lithic sandstone turbidites interbedded with medium-gray to black, massive, plane-laminated and crossbedded siltstone, and black shale. Sandstone beds range in thickness from $1 \mathrm{~cm}$ to $4 \mathrm{~m}$; mean values range from 15 to $20 \mathrm{~cm}$. Beds are laterally continuous and have sharp bases and sharp or gradational tops. Amalgamated beds and sbale rip-up layers are rare, but well-preserved flute casts are common. This unit is characterized by alterwating sandand shale-dominated sequences that range to $25 \mathrm{~m}$ and $3 \mathrm{~m}$, respectively. The sand to shale ratio is as high as 50:1, averages about $4: 1$, and locally is less than 1:1. Both thickening- and coarsening-upward, and thinning- and finingupward megacycles occur. Bouma (1962) intervals in sandstones include massive or graded $\mathrm{T}_{a b}, \mathrm{~T}_{\text {ae }}, \mathrm{T}_{\text {abcde }}, \mathrm{T}_{b c d e}, \mathrm{~T}_{c d e}, \mathrm{~T}_{c e}$, and $\mathrm{T}_{\text {de. }}$. Bouma interval $\mathrm{T}_{\mathrm{ce}}$ is dominant, and these rocks show internal cross-lamination, sharp bases, and sharp tops. Bouma intervals in shaly sections com. posed of fine- to very fine grained sands and shale include $T_{b c d e}, T_{c d e}$, and $T_{d e} ; T_{d e}$ is dominant. Shaly sections are composed of repeated 1 - to 3-cm-thick turbidite beds interlayered with black shale. Thin sands have either sharp or gradational tops and are interpresed to be facies $\mathrm{D}$ 
and $E$ deposits; medium-bedded sandstone sequences assigned to facies $C, D$, and $E$; suggests middle- and outer-fan deposition

\section{THICK-BEDDED SANDSTONE AND} SHALE-Light- 10 dark-gray, very coarse to very fine grained, massive, graded, plane-laminated and cross-laminated lithic sandstone turbidites interbedded with black, massive, plane-laminated and cross-laminated siltstone and silty shale. Sandy, pebbly, and chaotic mudstones also occur locally. Unit characterized by thick altemating sequences of sandstone and shate with sand to shale ratios of 100:1 to 1:1,000 (commonly about $10 ; 1)$

Sandstone beds from $<1 \mathrm{~cm}$ to $>5.5 \mathrm{~m}$ thick (mean thickness $=0.4 \mathrm{~m}$ ) occur in massive shale sections, either as thin, laterally discontinuous beds with sharp bases and tops, or as thick, commonly amalgamated beds with scoured bases and gradational tops; contain diffuse laminations composed of shale-chip intraclasts (see Kuskokwim Group stratigraphic section, sheet 2). Other bedding features include load, fluse, and groove casts. Paleocurnent indicators suggest a southwesterly transport direction (fig. 1). Shale-chip intraclasts range in long dimension from microscopic to $7 \mathrm{~cm}$ and may occur at any level in the enclosing sandstone bed. Bouma intervals in sandstone-dominated sections include $T_{a}, T_{a e}, T_{a b}$, and $T_{a b e}$ and subordinate $T_{\infty e}$ and $T_{c d e}$. Bouma intervals in shale-dominated sections include parallellaminated $\mathrm{T}_{\mathrm{de}}$ and subordinate, thin $\mathrm{T}_{\mathrm{ac}}$ and $\mathrm{T}_{\mathrm{cde}}$; sandstone and siltstone intervals all have sharp bases and tops. Some shale-dominated sections are composed of poorly sorted sandy and pebbly (sometimes chaotic) mudstones, which are matrix-supported and contain clasts of angular to nebulitic shale and sandstone intraclasts and Inoceramus sp. fragments. Pebbly mudsrones correspond to facies $\mathbf{F}$ chaotic deposits, whereas sandstone-dominated sections correspond mainly to facies $B$, and the shale-dominated sections to facies $D$ and $G$. Facies associations indicate inner-fan deposition.

Unit also characterized by moderately to welldeveloped foliation, structurally dismembered sandstone phacoids in deformed sbale, moderate recrystallization, grain elongation up to $2: 1$, highly shattered and flaggy outcrops, and local white quartz veins. Swale and ridge topography reflects alteration of sandstone and shale; however, structural deformation, including faulting, foliation, and isoclinal and open folding, masks lateral continuity of bedding

KKq MINERALIZED QUARTZ VEINS AND QUARTZ-VEIN STOCKWORK AND HORNFELS-Near Fortyseven Creek: T. $11 \mathrm{~N}$., R. 50 W; (secs. 8, 17, and 18) brown-weathering hornfelsed clastic sediments with mineralized quartz veins and quartz-vein stockwork. Homfelsed zone is adjacent to small myolite bodies. The brown-weathering character and fine-grained mineral latbs distinguish this hornfels zone from nonhornfelsed rocks and from otber nonmineralized hornfels. Southwest of Fortyseven Creek, a hornfelsed zone similar to the zone at Fortyseven Creek may represent an extension of the Fortyseven Creek trend. Quartz veins and their alteration selvages contain native gold, scheelite, and arsedopyrite. The Fortyseven Creek occurrence also contains wolframite, arsenopyrite, pyrite, jamesonite, stibrite, argentite, and traces of gold-silver tellurides; tourmaline and sericite accompany quartz gangue (Cady and others, 1955). On Fortyseven Creek downstream from the main mineralized shear zone, two distinct mineralized borizons occur in placer deposiss: gold concentrations on bedrock and small amounts of gold distributed in gravels above bedrock, and gold and scheelite concentrations on a yellow clay false bedrock

Kkh HORNFELSED SANDSTONEAND SHALEHornfelsed clastic rocks of the Kuskokwim Group occur adjacent to plutons, stocks, and dikes. Intensely hornfelsed rock contains poikiloblastic biotite; very fine grained, subhedral, granular zoisite(?); sparse euhedral pyrite; black-tourmaline rosettes; and fibrous sillimanite. These inner-zone minerals are enclosed in completely recrystallized detrital grains and, rarely, by myrmekise; visible biotite found adjacent to large igneous bodies

KJs CALCAREOUS SANDSTONE, SILTSTONE, AND SHALE-Medium-brown and dark-gray, light-reddish-brown-weathering sandsrone, siltstone, and shale; locally crosscut by quartz and carbonate veinlets; sandstone is generally medium grained and poorly sorted; contains abundant carbonate fossil fragements; larger fragments west of Kiokluk Mountains have been identified as Inoceramus sp. (of probable 
Cretaceous age, table 4, map no. VI). Contact relationships with units in repon area obscured by Quaternary deposits

\section{Holitna Group}

DSb LIMESTONE AND DOLOMITE-Very light to medium-gray, thin- to massive-bedded, finely laminated, limy and dolomitic mudstone to wackestone with interbeds of grainstone. Represents shallow, subtidal to peritidal cyclic carbonate sedimentation (Clough and others, 1984). Commonly fossiliferous in subtidal wackestone to grainstone facies. Locally recrystallized and brecciated in areas adjacent to faults. Estimated thickness of Holitna group in the central Kuskokwim region is 1,500 to 3,000 $\mathrm{m}$ (Cady and others, 1955). Age in map area is Silurian to Devonian, on the basis of our litbologic correlation with equivalent. megafossil-bearing strata in the Kulukbuk Hills, approximately $14 \mathrm{~km}$ east of map area

\section{INTRUSIVE ROCKS}

Tir/ ALBITE RHYOLITE AND ALBITE RHYOTird/ LITE PORPHYRY - Medium-light-gray to buff, Tirg fine-10 medium-grajoed, porphyritic, biotite-albite rhyolite and white mica-biotite-albite rhyolite porphyry. Tertiary age assigned on the basis of inerusive relationship with Upper Cretaceous Kuskokwim Group and three K-Ar ages on white mica $(61.7,63.6$, and $61.5 \mathrm{Ma}$, table 3$)$. Biotite-albite thyolite is characterized by euhedral and subhedral grains of quartz, albite, biotite and sanidine in a matrix of very fine grained quartz, feldspar, and aitered glass. Geochemistry indicates a rhyolite to rhyodacite range (table 1). Quartz phenocrysts contain resorbed rims and resorption channels. Sanidine and albite are aftered to fine-grained white mica and clay minerals locally. Subhedral grains of biotite to $8 \mathrm{~mm}$ across are fresh and appear to be primary phase of rhyolite. Minor white mica (muscovite?) occurring as subhedral grains to $5 \mathrm{~mm}$ across appears also to be primary. Scattered subhedral to euhedral grains of dark-blue tourmaline occur throughout rhyolite. Near western flank of Holokuk Mountain, a breccia body contains angular to rounded fragments of tourmalinized rhyolite and rhyolite porphyry set in matrix of quartz and tourmaline. Where phenocrysts of quartz and feldspar become dominant constituent, unit is thyolite porphyry. No stratigraphic evidence for age exists other than apparent intrusive relationship into Kuskokwim Group. Similar albite rhyolite on Barometer Mountain (near Sleetmute, nortbeast of map area) yielded one minimum whole-rock K-Ar age of $67.9 \pm 2.0 \mathrm{Ma}$ and one $\mathrm{K}$-Ar age on biotite of $70.5 \pm 2.1 \mathrm{Ma}$ (DGGS unpublished data, 1984); relationship with this unit is unclear

Tird-Greenish medium-gray, fine-grained, altered, porphyritic quariz-plagioclase feldspar rhyolite phase. These non-biotite rocks are deeply weathered, with green clots of dickite(?)

Tirg-Medium-gray, fine-grained, porphyritic garnet-biotite rhyolite. Medium-grained garnet and biotite in fine-grained, potassium-feldsparrich matrix

TKii HYPABYSSAL INTERMEDIATE INTRUSIVE ROCKS-Medium-gray and light-gray porphyritic quartz diorite to granodiorite with medium-grained hornblende and plagioclase phenocrysts (mean length $=3 \mathrm{~mm}$ ) in finegrained matrix of randomly to slightly oriented plagioclase laths. Intrudes Upper Cretaceous Kuskokwim Group. Forrns dikes and small stocks. Locally, quarz monzonite to granite occur, containing potassium feldspar phenocrysts to $3.5 \mathrm{~cm}$ long and medium-grained quartz and biotite phenocrysts. Extensive hydrothermal alteration products include calcite, chlorite, epidote, opaque minerals, and fine-grained white mica

TKi APLITE-Light- to dark-gray and buff, fine- to medium-grained aplite dikes composed of quartz, porassium feldspar, and plagioclase feldspar, with minor white mica, biotite, and hornblende

TKif FELSITE DIKES-Light-gray to buff, finegrained felsite dikes containing disseminated, fresh or oxidized pyrite cubes, or euhedral garnet

Kkgd GRANODIORITE TO GRANITE OF THE KIOKLUK MOUNTAINS-Medium- to darkgray, nonfoliate hypidiomorphic-granular. medium- and coarse-grained hornblende-biotite and biotite-hornblende granodiorite to granite. Geochemistry indicates a granite to quartz monzonite composition (table 1). The color index is approximately 18 . The Cretaceous age of Kiokluk pluton is based on the K-Ar age of one biotite separate: $68.7 \pm 2.1 \mathrm{Ma}$ (table 3). 
Plagioclase $\left(A n_{35}\right)$ is subhedral to euhedral and is slightly altered to fine-grained white mica, locally to epidote. Quartz is anhedral and medium to fine grained. Potassium feldspar is typically medium grained, occurs as subhedral and euhedral grains to $7 \mathrm{~mm}$ long, and locally forms rosettes. Biotite occurs as $0.5-$ to $3.0-\mathrm{mm}$ subbedral to anbedral grains that constitute 5 to 8 percen of the rock and may surround hornblende, producing mafic mineral clots. Hornblende occurs as 2-to 4-mm-long subhedral grains that form 6 to 12 percent of the rock and is moderately altered to white mica, chlorite, epidote, and opaque minerals; accessory apatite is common. Quartz-tourmaline veins and minor greisens occur locally

Kcgd/ GRANODIORITE AND GRANITE OFTHE $\mathrm{Kcg}$ CHUILNUK MOUNTAINS-Medium- to darkgray, nonfoliate bypidiomorphic-granular, medium-grained, hornblende- biotite granodiorite. Two geochemical analyses indicate a granodiorite composition (table I). Textures range from equigranular to seriate and porphyritic. Plagioclase feldspar $\left(\mathrm{An}_{38}\right)$ is the predominant feldspar and occurs as subhedral to euhedral grains to $10 \mathrm{~mm}$ long. Pocassium feldspar usually occurs as interstitial, anhedral grains. Biotife occurs as subhedral grains from 1 to $3 \mathrm{~mm}$ across and constitutes to 11 percent of rock. Hornblende occurs as subhedral grains and anhedral masses to $4 \mathrm{~mm}$ long and constitutes 2 to 10 percent of rock. Quartz occurs as anhedral masses that constitute $>8$ percent of rock. Accessory minerals include zircon, apatite, and opaques. Locally, granodiorite is hydrothermally altered to chlorite, white mica, epidote, and minor calcite. Crosscutting quartz-tourmaline veins occur locally and are characterized by thin selvages of tourmaline surrounding quartz-dominant vein centers. Granodiorite yielded $\mathrm{K}$-Ar ages on biotite of $67.5 \pm 2.0 \mathrm{Ma}$ and $68.4 \pm 2.1 \mathrm{Ma}$ (table 3). The border phase, near the eastern and northern boundaries of Chuilnuk pluton ( $\mathrm{Kcg}$ ), is light- to medium-gray, nonfoliate, seriate to porphyritic, medium- to coarse-grained granite. One geochemical analysis indicates a granite composition (table 1). Potassium feldspar occurs as euhedral and subhedral phenocrysts to $10 \mathrm{~mm}$ long and as subhedral masses in groundmass. Biotite occurs as subhedral grains that constinste to 10 percent of rock; minor homblende is also present. Accessory zircon and apatite are common, and epidote, sericite, and chlorite occur where granite is hydrothermally altered. Two $\mathrm{K}$-Ar ages on biotite separates from the granite phase $(\mathrm{Kcg})$ are $68.7 \pm 2.1 \mathrm{Ma}$ and $67.5 \pm 2.0 \mathrm{Ma}$ (table 3)

Kgi GRANODORITE-Small granodiorite intrusion in northeastern part of Sleetmute B.5 Quadrangle; age and relationship to other granodiorite intrusions uncertain

Kii INTERMEDIATE TO MAFIC STOCKS AND DIXES-Mediur - to dark-gray, mediumgrained, granodiorite and biotite, quartz-bearing gabbro. Intsudes Upper Cretaceous Kuskokwim Group. A minimum K-Ar age on one homblende separate is $63.8 \pm 1.9 \mathrm{Ma}$ (table 3 ); unit crosscut by andesite dike unit (Kim), which is dated at $69.8 \pm 2.1 \mathrm{Ma}$. Textures range from equigranular in stocks to porphyritic in dikes. Plagioclase $\left(\mathrm{An}_{50}\right)$ occurs as grains to $3 \mathrm{~mm}$ long in stocks and to $4.5 \mathrm{~mm}$ long in porphyritic rocks Augite occurs locally, forming to 15 percent of rock in a mafic border phase of stocks and to 5 percent in one dike. Asteration is moderate; products include fine-grained white mica, chlorite, carbonate and opaque minerals

Kim ANDESITE DIKES-Medium- to dark-gray, fine- to medium-grained andesite containing subhedral plagioclase as dominant feldspar and locally minor quartz and potassium feldspar. Geochemical analysis yields an andesitic composition (table 1). Andesite dikes crosscut lower(?) part of incerlayered lahar deposits and basaltic andesite unit (Khlb) which bas been radiometrically dated at $73.2 \pm 2.2 \mathrm{Ma}$. One K-Ar age is $69.8 \pm 2.1 \mathrm{Ma}$ (table 3). Andesite dikes also crosscut the intermediate to felsic flows, tuff, and agglomerate unit (Khf), the felsite breccia unit (Khb), and the intermediate to mafic stocks and dikes unit (Kii). Mafic-mineral content variable: includes biotite and homblende. Andesite dikes altered locally; plagioclase altered to clay minerals, some of which are green (dickite?), biotite to chlorite, and hornblende to biotite and epidote

\section{ACKNOWLEDGMENTS}

We thank T.K. Bundtzen, DGGS, and S.E. Box, U.S. Geological Survey, for their thoughtful reviews, and Robert Blodgett, U.S. Geological Survey, for his comments. 


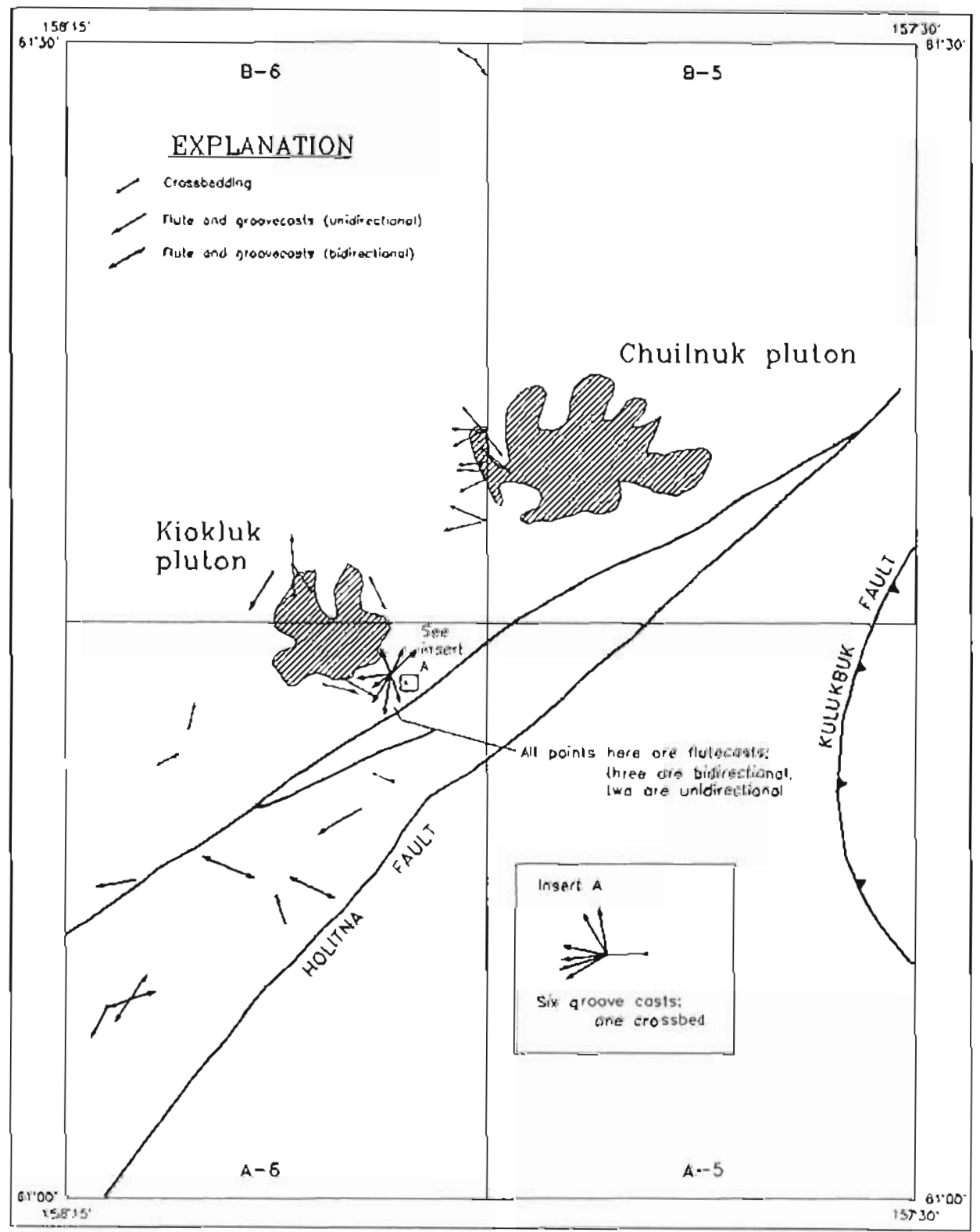

Figure 1. Paleocurrent data for the Sleetmute A-5, A-6, B-5, and B-6 Quadirangles. Dara have been corrected for tectonic dip.

\section{REFERENCES CITED}

Adrain, J.M., Chat1erton, B.D.E., and Blodgelt, R.B.. in press, Silurian trilobites from southwestern Alaska: Journal of Paleontology.

Bouma, A.H., 1962, Sedimentology of some Clysch deposits: Amstcrdam, Elsevier, $168 \mathrm{p}$.

Box, S.E. and Elder, W.P., 1992, Depositional and biostratigraphic framework of the Upper Cretaceous Kuskokwim Group. southwesiem Alaska, in Bradley, D.C.. and Ford, A.B. (eds.), Geologic studies in Alaskat: U.S. Geological Survey, Bulletin 1999, p. 8-16. Bunduen. T.K. and Laird, G.M. 1982, Geologic map of the Iditarod D-2 and eastern D-3 Qundrangles. Alaska: A laska Division of Gcological \& Geophysical Surveys Geologic Repor 72.1 sheet, scale 1:63,360.

1983. Geologic map of the McGrath D-6 Quadrangle: Alaska Division of Geological \& Geophysical Surveys Professional Repor 79, I shee1, scale 1:63,360.

1991, Geology and nineral resources of the Russian Mission C.1 Quadrangle, southwest Alaska: Alaska Division of Geological \& Geophysical Surveys Professional Report 109, 24 p., 2 sheets, scale 1:63,360.

1992, Geology and mineral resources of Iditarod mining district, Iditarod D-4 and eastem B-5 Quadrangles. 
west-central Alaska: Alaska Division of Geological \& Geophysical Surveys Professional Report 97, 88 p., 2 sheets, scale I:63,360.

Cady, W.M., Wallace, R.E., Hoare, J.M., and Webber, E.J., 1955, The central Kuskokwim region, Alaska: U.S. Geological Survey Professional Paper 268, 132 p.

Clough. J.G., Blodgett, R.B., and Smith. T.N, 1984, Middle Paleozoic subtidal to tidal flat carbonate sedimentation in southwest Alaska [abs.]: Geological Society of America Abstracts with Progtams, v. 16, no. 5, p. 275.

Cobb, E.H., 1976, Summary of references to mineral occurrences (other than mineral fuels and construction materials) in the Dillingham. Sleetmute, and Taylor Mountains Quadrangles, Alaska: U.S. Geological Survey Open-File Report 76-606, $92 \mathrm{p}$.

Decker, John, Bergman, S.C., Blodgett, R.B., Box, S.E., Bundtzen, T.K., Clough, J.G., Coonrad, W.L., Gilbert. W.G., Miller, M.L., Murphy, J.M., Robinson, M.S., and Wallace, W.K., 1994, Geology of southwestern Alaska, in Plafker, G., and Berg, H.C., eds., The Geology of Alaska: Boulder, Colorado. Geological Sociely of America, The Geology of North America, v. G-1, p. 285-310, plate 3. scale $1: 2,500,000$.

Decker, John, Reifenstuhl, R.R., and Coonrad, W.L., 1984, Compilation of geologic data from the Sleetmute B-5 Quadrangle, southwestern Alaska; Alaska Division of Geological \& Geophysical Surveys Public-data File 84-44, 1 sheet, scale 1:63,360.

Decker, John, Robinson, M.S., Murphy, J.M., Reifensiuhl, RR., and Albanese, M.D., 1984, Geologic map of the Sleetrute A-6 Quadrangle, Alaska: Alaska Division of Geological \& Geophysical Surveys Report of Investigations 84-8, 1 sheet, scale 1:40,000.

Elder, W.P., and Box, S.E., 1992, Late Cretaceous inoceramid bivalves of the Kuskokwim basin, southwestem Alaska, and their implications for basin evolution, Journal of Paleontology Memoir 26, $39 \mathrm{p}$.

Elder, W.P., and Milier, J.W., 1991, Maps showing fossil localities and checklists of Jurassic and Cretaceous macrofauna of western Alaska, U.S. Geological Survey Open-Pile Report 91-629, 72 p., 3 sheets, scale $1: 500,000$.

Miller, M.L. and Bundtzen, T.K., 1994, Genecalized geologic map of the Iditarod Quadrangle, Alaska, showing potassium-argon, major-oxide trace-element. fossil. paleocurnent, and archacological sample localities: U.S. Geological Survey, Miscellaneous Field Studies Map, 48 p., I sheet, scale $1: 250,000$.

Moll-Stalcup. E.J., 1994, Latest Cretaceous and Cenozoic magmatisn in mainland Alaska in Plafker, G., and Berg, H.C., eds., The Geology of Alaska: Boulder, Colorado. Geological Society of America, The Geology of North
America, v. G-1, p. 589-619, plates 1, 2, 3, 5, scale $1: 2,500,000$.

Moore, T.E., and Wallace, W.K., 1985, Submarine-fan facies of the Kuskokwim Group, Cairn Mountain area, soutb. western Alaska (abs.), Geological Society of America Abstract with Programs, v. 17, no. 6, p. 371.

Murphy, J.M., Decker, John, Reifensturhl, R,R., and Coonrad, W.L.. 1984, Compilation of geologic data from the Sleetmute B-6 Quadrangle, southwestern Alaska: Alaska Division of Geological \& Geophysical Surveys Publicdatu File 84-6, I sheet, scale 1:63,360.

Mutti, Emiliano, and Ricci Lucchi، Franco, 1972, Le torbiditi dell'Appenino settentrional-introdusione all'analisi de facies [Turbidites of the northern Apennines-introduction to facies analysis]-with English summary: Memoire del la Societa Geologic Italiana, v. 11, p. 161-199.

Peccerillo, Angelo, and Taylor, S.R., 1976, Geochemistry of Eocene calc-alkaline volcanic rocks from the Kastamonu area, northem Turkey: Contributions to Mineralogy and Petrology, v. 58, no. 1, p. 63.81.

Reifenstuhl, R.R., Decker, John, Murphy, J.M., and Coostrad, W.L., 1984, Compilation of geologic data from the Sleetmute A-6 Quadrangle, southwestern Alaska: Alaska Division of Geological \& Geophysical Surveys Publicdata File $84-43,1$ sheet, scale $1: 63,360$.

Reifenstuhl, R.R., Robinson, M.S., Smith, T.E., Albanese, M.D., and Allegro. G.A., 1984, Geologic map of the Sleetmute B-6 Quadrangle, Alaska: Alaska Division of Geological \& Geophysical Surveys Report of Investigations 84-12, 1 sheet, scale 1:40,000.

Robinson, M.S., 1984a, Rock. pan-concentrate and stream-sediment geochemistry, Sleetmute A-6 Quadrangle, Alaska: Alaska Division of Geological \& Geophysical Surveys Report of Investigations 84-7, 1 sheet, scale 1:40,000.

1984b, Rock, pan-concentrate and stream-sediment geochemistry, Sieetmute B-5 Quadrangle, Alaska: Alaska Division of Geological \& Geophysical Surveys Report of Investigations 84-9, 1 sheet, scale 1:40,000.

-1984c, Rock, pan-concentrate and stream-sediment geochemistry, Sleetmute B-6 Quadrangle, Alaska: Alaska Division of Geological \& Geophysical Surveys Report of Investigations $84-11,1$ sheet, scale 1:40,000.

Robinson, M.S., Decker, John, Reifenstuhl, R.R., Murphy, J.M., and Box, S.E, 1984, Geologic map of the Sleetmute B-5 Quadrangle, Alaskz: Alaska Division of Geological \& Geophysical Surveys Report of Investigations 84-10, I sheet, scale $1: 40,000$.

Sainsbury, C.L., and MacKevetr, E.M., Jr., 1965, Quicksilver deposits of southwestern Alaska: U.S. Geological Survey Bulletin $1187,89 \mathrm{p}$. 
Table 1. Major oxide geochemical analysis of rock samples ${ }^{2}$

\begin{tabular}{|c|c|c|c|c|c|c|c|c|c|c|c|c|c|c|c|}
\hline $\begin{array}{l}\text { Map } \\
\text { no. }\end{array}$ & Rock type ${ }^{6}$ & $\begin{array}{l}\text { Map } \\
\text { writ }\end{array}$ & $\mathrm{SiO}_{2}$ & $\mathrm{Al}_{2} \mathrm{O}_{3}$ & $\mathrm{Fe}_{2} \mathrm{O}_{3}$ & $\mathrm{FeO}$ & $\mathrm{MgO}$ & $\mathrm{CaO}$ & $\mathrm{Na}_{2} \mathrm{O}$ & $\mathrm{K}_{2} \mathrm{O}$ & $\mathrm{TiO}_{2}$ & $\mathrm{P}_{2} \mathrm{O}_{5}$ & $\mathrm{MnO}$ & LOF $^{\mathrm{C}}$ & Total \\
\hline 1 & Basaltic andesite & Khap & 54.81 & 16.64 & 3.41 & 5.62 & 4.61 & 6.62 & 3.33 & 1.95 & 1.16 & 0.22 & 0.13 & 0.95 & 99.45 \\
\hline 2 & Basaltic andesite & Klbap & 53.84 & 17.23 & 4.33 & 5.14 & 2.32 & 6.69 & 350 & 1.35 & 1.64 & 0.24 & 0.13 & 3.54 & 99.95 \\
\hline 3 & Rhyolite & Tir & 70.98 & 14.82 & 2.44 & 1.18 & 0.23 & 1.33 & 3.81 & 3.72 & 0.11 & 0.03 & 0.02 & 1.00 & 99.67 \\
\hline 4 & Rhyolite & Tir & 68.36 & 15.06 & 3.31 & 2.29 & 0.92 & 1.95 & 3.71 & 3.41 & 0.56 & 0.13 & 0.07 & 123 & 101.00 \\
\hline 5 & Dacite & Khap & $\$ 7.68$ & 16.77 & 2.41 & 6.47 & 4.39 & 6.05 & 3.48 & 1.76 & 1.03 & 0.17 & 0.14 & 0.01 & 100.36 \\
\hline 6 & Basaltic andesite & Khap & 55.35 & 16.45 & 2.38 & 6.56 & 4.92 & 6.95 & 3.55 & 1.63 & 0.91 & 0.13 & 0.13 & 0.19 & 99.15 \\
\hline 7 & Batsaltic andesite & $T v_{\Gamma_{2}}$ & 54.73 & 14.79 & 4.20 & 6.12 & 2.53 & 5.44 & 3.80 & 3.03 & 1.97 & 0.27 & 0.15 & 2.49 & 99.52 \\
\hline 8 & Rhyolite & $T v_{3}$ & 75.74 & 11.99 & 2.59 & 0.56 & 0.08 & 0.44 & 3.39 & 4.54 & 0.17 & 0.02 & 0.02 & 0.52 & 100.06 \\
\hline 9 & Rhyolite & $\mathrm{TVr}_{3}$ & 76.02 & 11.71 & 2.52 & 0.59 & 0.05 & 0.36 & 3.15 & 4.97 & 0.17 & 0.02 & 0.02 & 0.31 & 99.89 \\
\hline 10 & Rhyotice & $\mathrm{TVr}_{3}$ & 75.00 & 1320 & 2.67 & 0.09 & 0.22 & 0.19 & 2.56 & 4.64 & 0.20 & 0.02 & 0.00 & 3.07 & 99.88 \\
\hline 11 & Basaltic andesite & Khap & 53.77 & $\lfloor 6.51$ & 4.37 & 4.04 & 4.45 & 6.13 & 2.57 & 1.85 & 1.12 & 0.18 & 008 & 5.18 & 10025 \\
\hline 12 & Basaltic andesite & Khap & 54.01 & 15.52 & 3.50 & 5.77 & 6.95 & 7.50 & 2.86 & 1.20 & 0.85 & 0.12 & 0.14 & 1.63 & 100.05 \\
\hline 13 & Quartz latite & Khlb & 70.12 & 14.75 & 2.85 & 0.90 & 0.59 & 1.71 & 2.78 & 3.94 & 0.19 & 0.04 & 0,02 & 1.63 & 99.52 \\
\hline 14 & Quaraz latite & $\mathrm{KTH}_{1}$ & 70.29 & 15.00 & 2.84 & 0.87 & 0.56 & 1.54 & 2.93 & 3.92 & 0.20 & 0.04 & 002 & 132 & 99.53 \\
\hline 15 & Basalic andesite & Khìb & 51.36 & 16.43 & 6.37 & 3.69 & 5.72 & 9.45 & 3.20 & 0.72 & 1.22 & 0.13 & 0.34 & 1.18 & 99.61 \\
\hline 16 & Basatic andesite & KhJb & $\$ 4.46$ & 14.51 & 4.15 & 5.16 & 7.53 & 7.57 & 2.97 & 1.39 & 0.85 & 0.11 & 0.14 & 0.70 & 99.34 \\
\hline 17 & Andesite & Kh?th & 54.86 & 13.21 & 4.07 & 4.99 & 9.77 & 7.04 & 2.80 & 1.35 & 0.78 & 0.12 & 0.13 & 0.39 & 99.50 \\
\hline 18 & Rhyolite & Tir & 74,06 & 14.58 & 249 & 0.56 & 0.05 & 0.32 & 3.09 & 3.47 & 0.04 & 0.73 & 0.06 & 1.71 & 101.16 \\
\hline 19 & Rhyclite & Tir & 71.56 & 14.93 & 2.58 & 0.64 & 0.01 & 0.26 & 4.72 & 3.41 & 0.01 & 0.75 & 0.06 & 0.98 & 99.91 \\
\hline 20 & Rhyolite & Tir & 71.65 & 15.02 & 2.50 & 0.72 & 0.01 & 0.23 & $4.6 !$ & 3.47 & 0.01 & 0.81 & 0.06 & 1,03 & 100.12 \\
\hline $2 \mathrm{t}$ & Rhyolite & Tir & 71.96 & $\$ 4.81$ & 2.58 & 0.64 & 0.01 & 0.24 & 4.74 & 3.41 & 0.01 & 0.77 & 0.06 & 0.98 & 100.21 \\
\hline 22 & Rbyolite & Tir & 70.72 & 15.67 & 2.26 & 0.99 & 0.01 & 0.27 & 4.93 & 3.39 & 0.01 & 0.45 & 0.12 & 0.79 & 99.61 \\
\hline 23 & Rhyolite & Tir & 70.82 & 15.60 & 2.72 & 0.55 & 0.01 & 0.24 & 4.89 & 3.49 & 0.01 & 0.43 & 0.06 & 0.73 & 99.55 \\
\hline 24 & Rhyodacite & Tit & 61.99 & 15.7 & 3.46 & 4.03 & 2.15 & 3.47 & 3.79 & 2.90 & 0.95 & $0.2 I$ & 0.12 & 1.48 & 100.32 \\
\hline 25 & Rhyolite & Tir & 71.30 & 15.78 & 2.53 & 0.46 & 0.01 & 0.32 & 4.40 & 3.67 & 0.01 & 0.36 & 0.07 & 1.10 & 100.01 \\
\hline 26 & Basaltic andesite & Kha & 54.38 & 14.60 & 3.84 & 5.49 & 8.38 & 6.69 & 2.94 & 1.25 & 1.01 & 0.14 & 0.14 & 0.26 & 99.12 \\
\hline 27 & Basaltic andesite & Kha & 54.65 & 14.85 & 3.91 & 5.31 & 8.01 & 6.72 & 2.95 & 1.18 & 1.02 & 0.15 & 0.15 & 0.41 & 99.31 \\
\hline 28 & Basaltic ardesite & Khap & 53.93 & 14.39 & 3.84 & 5.59 & 6.93 & 7.62 & 3.02 & $\$ .21$ & 1.19 & 0.17 & 0.15 & 1.75 & 99.79 \\
\hline 29 & Basaltic andesite & Khap & 54.19 & 16.27 & 4.51 & 5.17 & 5.95 & 7.95 & 2.99 & 1.36 & 1.02 & 0.36 & 0.14 & 0.77 & 100.48 \\
\hline 30 & Granite & $\mathrm{Kcg}$ & 7262 & 1323 & 2.78 & 1.02 & 0.31 & 1.16 & 3.33 & 4.45 & 0.26 & 0.03 & 0.03 & 0.31 & 99.53 \\
\hline 3] & Granokiorite & $\mathrm{Kcgd}$ & 63.66 & 15.62 & 3.18 & 3.73 & 2.02 & 3.79 & 3.77 & 2.92 & 0.91 & 0.14 & 0.10 & 0.71 & 100.55 \\
\hline 32 & Granodionite & Kegd & 65.18 & 16.09 & 1.52 & 3.61 & 1.77 & 3.78 & 3.54 & 3.26 & 0.86 & 0.15 & 0.10 & 0.28 & 100.14 \\
\hline 33 & Basaltic andcsice & Khaa & 53.34 & 16.10 & 4.26 & 4.75 & 5.80 & 8.13 & 2.99 & 0.90 & 0.82 & 0.11 & 0.13 & 3.02 & $\$ 00.35$ \\
\hline 34 & Andesite & $\mathrm{Kim}$ & 63.24 & 15.66 & 3.11 & 2.97 & 2.75 & 2.87 & 4.45 & 3.37 & 0.60 & 0.16 & 0.05 & -- & 99.23 \\
\hline 35 & Andesite & Khaa & 58.45 & 14.89 & 4.14 & 3.45 & 5.49 & 5.92 & 3.03 & 1.49 & 0.79 & 0.12 & 0.09 & 2.67 & 100.53 \\
\hline 36 & Andesite & Khf & 59.45 & 13.37 & 2.82 & 4.49 & 6.03 & 5.26 & 2.83 & $3.2 !$ & 0.56 & $0.2 \mathrm{I}$ & 0.10 & 1.59 & 99.92 \\
\hline 37 & Quartz monzonite & Kkgd & 63.66 & 15.62 & 3.18 & 3.73 & 2.02 & 3.79 & 3.77 & 2.72 & 0.91 & 0.14 & 0.10 & 0.71 & 100.35 \\
\hline 38 & Quartz monzonite & Kkgd & 64.56 & 14.94 & 2.65 & 3.33 & 2.81 & 3.63 & 3.15 & 3.83 & 0.66 & 0.13 & 0.08 & 0.58 & 100.35 \\
\hline 39 & Quartz monzonite & Kkgd & 63.77 & 14.78 & 2.81 & 3.40 & 2.89 & 3.78 & 3.14 & 3.85 & 0.66 & 0.14 & 0.08 & -- & 99.30 \\
\hline 40 & Homfels & Kkh & 66.97 & 8.55 & 2.27 & 3.23 & 3.51 & 10.48 & 1.53 & 1.17 & 0.48 & 0.13 & 0.07 & $=-$ & 98.39 \\
\hline 41 & Basaltic andesite & Khaa & 54.90 & 15.29 & 3.52 & 5.68 & 8.11 & 6.56 & 3.12 & 1.22 & 0.99 & 0.13 & 0.14 & 0.43 & 100.09 \\
\hline 42 & Dacite & TKff & 58.44 & 15.08 & 3.11 & 3.31 & 2.87 & 3.83 & 5.62 & 1.11 & 0.71 & 0.13 & 0.08 & 0.97 & 95.26 \\
\hline 43 & Aplite & TKif & 72.32 & 15.08 & 252 & 0.46 & 0.02 & 0.29 & 4.88 & 3.57 & 0.03 & 0.03 & 0.03 & 0.95 & 100.18 \\
\hline 44 & Dacite & Tkif & 69.63 & 14.36 & 2.64 & 3.01 & 0.92 & 1.61 & 3.33 & 3.96 & 0.55 & 0.19 & 0.08 & 0.58 & 100.86 \\
\hline
\end{tabular}

X-ray fluorescence analyses by the DGGS Goachemical Lab, Fairbanks, Alaska, Major oxide values are in percent.

peccerillo and Taylor (1976) classification system.

Loss on ignition.

- - = Not analyzed 
Table 1a. Normative mineralogy (calculated using U.S. Geological Survey Petcal program)

\begin{tabular}{|c|c|c|c|c|c|c|c|c|c|c|c|c|c|}
\hline \multirow[b]{2}{*}{$\begin{array}{c}\text { Map } \\
\text { no. }\end{array}$} & \multicolumn{13}{|c|}{ CIPW Norms } \\
\hline & Quart? & Cortundum & Orthoclase & Albite & Anorthite & Hyperstbene & Woltastonite & Diopside & Magnetite & Hemabte & Illmenste & Apatite & Total \\
\hline$i$ & 6,44 & - & 11.70 & 28.61 & 25.07 & 14.90 & $\therefore$ & 5.52 & 5.02 & $\cdots$ & 2.24 & 0.52 & $\{00,02$ \\
\hline 2 & 10.98 & -- & 8.27 & 30.72 & 28.33 & 7.75 & - & 3.63 & 6.51 & -- & 3.23 & 0.58 & 100.00 \\
\hline 3 & 31.90 & 2.21 & 22.28 & 32.67 & 6.49 & 0.59 & $\cdots$ & $=$ & 3.59 & - & 0.21 & 0.07 & 100.01 \\
\hline 4 & 2831 & 2.04 & 20.20 & 31.46 & 8.85 & 2.97 & $\therefore$ & - & 4.81 & $\therefore$ & 1.07 & 0.30 & 100.01 \\
\hline 5 & 8.66 & $\cdots$ & 10.36 & 29.34 & 24.85 & 17.72 & $\therefore$ & 3.24 & 3.48 & $=$ & 1.95 & 0.39 & 99.99 \\
\hline 6 & 3.43 & $\ldots$ & 9.54 & 29.75 & 29.31 & 19.27 & $=$ & 3.27 & 3.42 & $=$ & $1.7 \mathrm{I}$ & 0.30 & 100.00 \\
\hline 7 & 6.73 & .. & 18.45 & 33.54 & 14.79 & 6.92 & $\therefore$ & 9.19 & 6.28 & $\therefore$ & 3.86 & 0.64 & 100.00 \\
\hline 8 & -- & .. & -. & -- & -. & - & - & - - & -- & -- & - & -- & .. \\
\hline 9 & 38.05 & 0.54 & 29.49 & 26.77 & 1.66 & 0.13 & - & -. & 1.48 & 1.51 & 0.32 & 0.05 & 100.00 \\
\hline 10 & -- & - - & -. & - - & - . & -- & - & $\cdots$ & - - & -- & - - & $\cdots$ & .. \\
\hline 11 & 12.39 & . & 11.50 & 22.87 & 29.50 & 13.41 & $\ldots$ & 0.99 & 6.67 & - & 2.24 & 0.44 & 100.01 \\
\hline 12 & 6.06 & . & 7.21 & 24.59 & 26.38 & 20.15 & $\ldots$ & 8.54 & 5.16 & - & 1.64 & 0.28 & 100.01 \\
\hline 13 & 35.19 & 2.96 & 23.78 & 24.03 & 8.40 & 1.50 & - - & $=$ & 2.47 & 1.21 & 0.37 & 0.30 & 100.01 \\
\hline 14 & $=$ & .. & -. & $=$ & $\therefore$ & - & -. & . & - & -- & 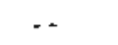 & $\ldots$ & - \\
\hline 15 & 5.49 & .. & 4.32 & 27.51 & 28.79 & 7.99 & - & 13.99 & 8.95 & 0.30 & 2.35 & 0.31 & 100.00 \\
\hline 16 & 6.40 & $\ldots$ & 7.13 & 25.48 & 23.06 & 18.56 & .. & 11.39 & 6.10 & - & 1.64 & 0.26 & 100,00 \\
\hline 17 & 5,13 & - & 8.05 & 23.90 & 19.66 & 23.77 & -- & 11.78 & 5.95 & - & 1.50 & 0.26 & 100.00 \\
\hline 18 & 42.97 & 5.77 & 20.62 & 26.29 & - - & 0.13 & - & - & 1.90 & 1.20 & 0.08 & - - & 98.96 \\
\hline 19 & 31.38 & $3.5 \mathrm{I}$ & 20.37 & 40.37 & - - & 0.03 & - & $\cdots$ & 2.25 & 1.05 & 0.02 & 1.54 & 100.52 \\
\hline 20 & 31.04 & 3.72 & 20.71 & 39.40 & - & 1.85 & - & $\ldots$ & 2.21 & $\cdots$ & 0.02 & 1.36 & 100.31 \\
\hline 21 & 31.57 & 3.35 & 20.31 & 40.42 & -. & 0.03 & - & $\cdots$ & 2.25 & 1.05 & 0.02 & 1,42 & 100.42 \\
\hline 22 & 29.33 & 3.94 & 20.27 & 42.21 & $=$ & 0.18 & - & $\cdots$ & 3.32 & - - & - - & 1.60 & 100.85 \\
\hline 23 & 29.36 & 3.82 & 20.87 & 41.87 & $=-$ & 0.03 & -. & - - & 1.96 & 1.40 & 0.02 & 1.42 & 100.75 \\
\hline 24 & 17.55 & 0.60 & 17.34 & 32.44 & 16.03 & 8.65 & - - & - - & 5.08 & - & $\ldots$ & 0.49 & 98.18 \\
\hline 25 & 32.00 & 4.62 & $2\{.93$ & 37.64 & . & 0.03 & $\cdots$ & - - & 1.70 & - - & 0.02 & 1.90 & 99.84 \\
\hline 26 & 5.65 & -- & 7.47 & 25.16 & 23.21 & 23.09 & $\therefore$ & 7.52 & 5.63 & $\cdots$ & 1.94 & 0.33 & 100.00 \\
\hline 27 & 6.66 & $\therefore$ & 7.05 & 25.24 & 24.06 & 2206 & $=-$ & 6.90 & 5.73 & $\therefore$ & 1.96 & 0.35 & 100.01 \\
\hline 28 & 6.37 & - - & 7.29 & 26.06 & 22.58 & 17,44 & -. & 11.88 & 5.68 & $=$ & 2.31 & 0.40 & 100.01 \\
\hline 29 & 6.66 & - - & 8.06 & 2537 & 27.03 & 14.84 & $=-$ & 9.17 & 6.56 & $\therefore$ & 1.94 & 0.37 & 100.00 \\
\hline 30 & 33.62 & 0.91 & 26.50 & 28.40 & 5.60 & 0.78 & - . & -- & 2.65 & 0.97 & 0.50 & 0.07 & 100.00 \\
\hline $3 t$ & 19.38 & - & 16.13 & 32.01 & 17.73 & 7.88 & - & 0.18 & 4.63 & - & 1.74 & 0.33 & 100.01 \\
\hline 32 & 19.95 & 0.23 & 19.29 & 29.99 & 17.80 & 8.56 & $\therefore$ & - - & 2.21 & -. & 1.64 & 0.35 & 100.02 \\
\hline 33 & 7.63 & $\cdots$ & 5.46 & 25.99 & $28.6 \mathrm{I}$ & 14.44 & $\therefore$ & 9.65 & 6.35 & - & 1.60 & 0.26 & 99.99 \\
\hline 34 & 13.95 & $\cdots$ & 20.68 & 37.94 & 12.90 & 8.75 & $\cdots$ & 0.32 & 4.54 & - & 2.15 & 0.37 & 100.60 \\
\hline 35 & 15.40 & $\therefore$ & 9.00 & 26.20 & 23.12 & 13.53 & $=$ & 4.80 & 6.13 & - & {$[.53$} & 0.28 & 99.99 \\
\hline 36 & 11.12 & $\therefore$ & 19.29 & 24.35 & 14.54 & [6.46 & $\therefore$ & 8.50 & 4.16 & - & 1.08 & 0.50 & 100.00 \\
\hline 37 & 15.98 & -. & 25.16 & 25.39 & 13.73 & 12.91 & - & 1.22 & 3.73 & - & 1.50 & 0.38 & 100.00 \\
\hline 38 & 19.07 & . & 22.68 & 26.71 & 15.35 & 9.29 & - & 1.49 & 3.85 & - & 1.26 & 0.30 & 100.00 \\
\hline 39 & 18.18 & - & 22.91 & 26.76 & 14.97 & 9.09 & $\ldots$ & 2.41 & 4.10 & .. & 1.26 & 0.33 & 100.01 \\
\hline 40 & 3350 & -. & 7.03 & 13.16 & 13.22 & - - & 2.87 & 25.65 & 3.35 & -. & 0.93 & 0.31 & 100.02 \\
\hline 41 & 5.16 & - & 7.23 & 26.49 & 24.19 & 23.53 & $=$ & 6.08 & 5.12 & -. & 1.89 & 0.30 & 99.99 \\
\hline 42 & 9.64 & - & 6.92 & 50.15 & 14.53 & 8.50 & - & 3.46 & 4.76 & -- & 1.42 & 0.32 & 99.70 \\
\hline 43 & 29.94 & 2.75 & 21.26 & 41.61 & 1.25 & 0.05 & - & - - & 151 & 1.50 & 0.06 & 0.07 & 100.00 \\
\hline 44 & 29.56 & 2.12 & 23.34 & 28.10 & 6.73 & 4.86 & -- & - & 3.82 & $\cdots$ & 1.04 & 0.44 & 100.01 \\
\hline
\end{tabular}


This page has intentionally been left blank. 


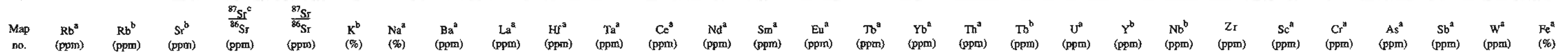

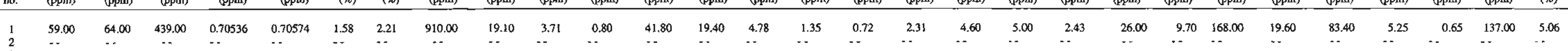

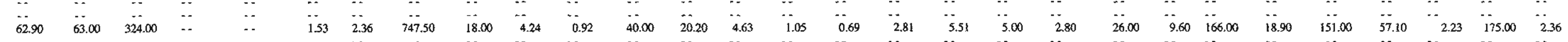

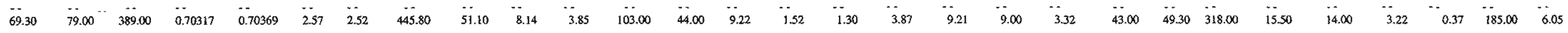

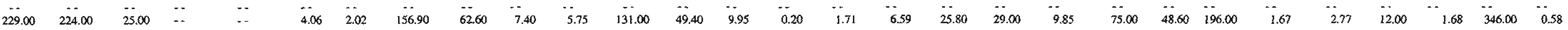

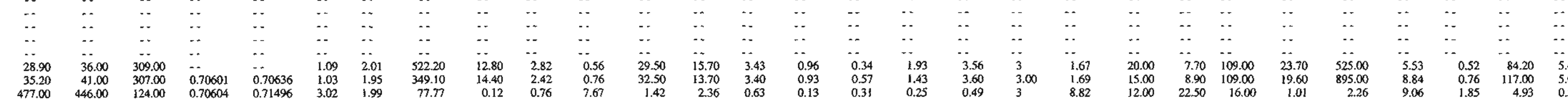

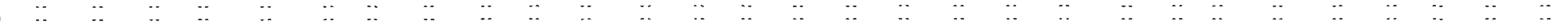

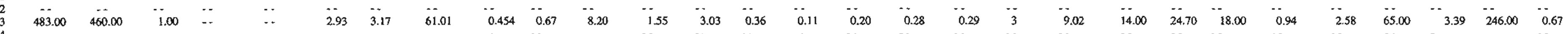

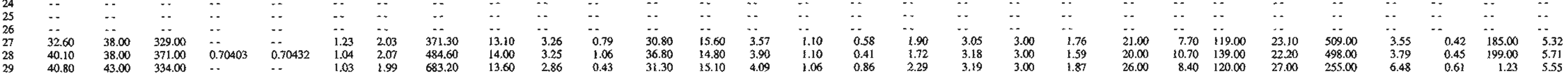

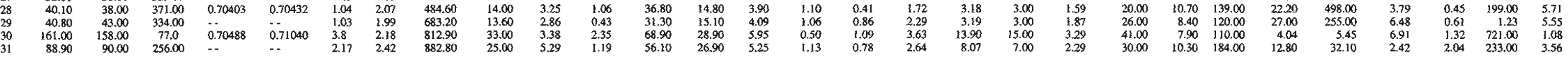

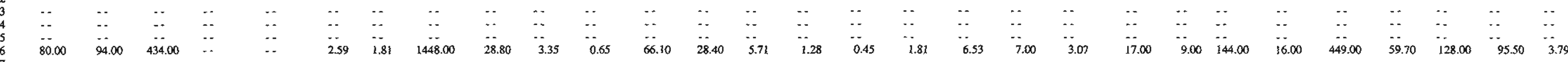

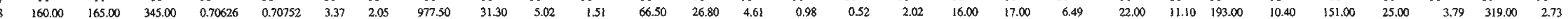

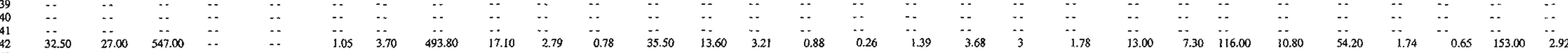


Table 3. K-Ar age analyses ${ }^{\mathrm{a}}$

\begin{tabular}{|c|c|c|c|c|c|c|c|c|}
\hline $\begin{array}{l}\text { Map } \\
\text { no. }\end{array}$ & $\begin{array}{c}\text { Rock } \\
\text { unit }\end{array}$ & $\begin{array}{l}\text { Mineral } \\
\text { dated }\end{array}$ & $\begin{array}{l}\mathrm{K}_{2} \mathrm{O} \\
\operatorname{wt}(\%)\end{array}$ & $\begin{array}{c}\text { Sample } \\
\text { wt(g) }\end{array}$ & ${ }^{40} \mathrm{Ar}_{\text {rad }} \times 10^{-11}$ & $\frac{{ }^{40} \mathrm{Ar}_{\mathrm{rad}}}{{ }^{40} \mathrm{~K} \times 10^{-11}}$ & $\frac{{ }^{40} \mathrm{Ar}_{\text {rad }}}{{ }^{40} \mathrm{Ar}_{\text {total }}}$ & $\begin{array}{l}\mathrm{Age}^{\mathrm{b}} \\
(\mathrm{Ma})\end{array}$ \\
\hline 1 & Khap & Plagioclase & 1.609 & 7.813 & 16.7 & 4.19 & 0.702 & $70.7 \pm 2.1^{\mathrm{c}}$ \\
\hline 2 & Khap & Plagioclase & 1.779 & 1.2043 & 18.5 & 4.20 & 0.834 & $70.8 \pm 2.1$ \\
\hline 3 & Tirg & Biotite & 5.574 & 0.1598 & 56.44 & 4.09 & 0.877 & $69.0 \pm 1.8$ \\
\hline 4 & Tir & Biotite & 8.548 & 0.206 & 79.6 & 3.76 & 0.469 & $63.6 \pm 1.9$ \\
\hline 5 & Khap & Whole rock & 1.61 & 7.813 & 17.6 & 4.42 & 0.669 & $74.5 \pm 2.2^{\mathrm{c}}$ \\
\hline 6 & Khap & Plagioclase & 1.202 & 1.9044 & 12.0 & 4.03 & 0.856 & $68.0 \pm 2.0$ \\
\hline 7 & $\operatorname{Trv}_{1}$ & Whole rock & 4.849 & 2.5464 & 30.9476 & 2.5763 & 0.5061 & $43.8 \pm 1.3$ \\
\hline 8 & Khap & Plagioclase & 0.28 & 3.0186 & 2.64 & 3.80 & 0.666 & $64.3 \pm 1.9$ \\
\hline 9 & Khlb & Whole rock & 1.35 & 8.5938 & 14.5 & 4.34 & 0.607 & $73.2 \pm 2.2^{c}$ \\
\hline 10 & Tir & White mica & 9.732 & 0.1189 & 10.4 & 3.64 & 0.833 & $61.7 \pm 1.8$ \\
\hline 11 & Tir & White mica & 9.685 & 0.2106 & 87.2 & 3.63 & 0.865 & $61.5 \pm 1.8$ \\
\hline 12 & Khap & Plagioclase & 0.51 & 2.8638 & 5.11 & 4.04 & 0.404 & $68.3 \pm 1.9$ \\
\hline 13 & $\mathrm{Kcg}$ & Biotite & 7.991 & 0.1139 & 80.5 & 4.07 & 0.859 & $68.7 \pm 2.1$ \\
\hline 14 & Kegd & Biotite & 7.609 & 0.2957 & 76.3 & 4.05 & 0.74 & $68.4 \pm 2.1$ \\
\hline 15 & Kcgd & Biotite & 8.423 & 0.5323 & 83.3 & 3.99 & 0.755 & $67.5 \pm 2.0$ \\
\hline 16 & Kkgd & Biotite & 7.097 & 0.1757 & 71.5 & 4.07 & 0.889 & $68.7 \pm 2.1$ \\
\hline 17 & Kkgd & Hornblende & 0.358 & 1.0787 & 3.62 & 4.08 & 0.578 & $68.9 \pm 2.1$ \\
\hline 18 & $\mathrm{Kii}$ & Hornblende & 0.683 & 0.8824 & 6.39 & 3.78 & 0.272 & $63.8 \pm 1.9$ \\
\hline 19 & Kim & Biotite & 1.45 & 0.124 & 14.85 & 4.13 & 0.657 & $69.8 \pm 2.1$ \\
\hline 20 & Tvb & Whole rock & 1.532 & 8.7988 & 8.51 & 2.41 & 0.806 & $38.2 \pm 1.1$ \\
\hline 21 & $\mathrm{Kkq}$ & White mica & 0.755 & 0.1442 & 87.03 & 3.6 & 0.866 & $60.9 \pm 1.8$ \\
\hline
\end{tabular}

analyses by J.D. Blum and D.L. Turner, DGGS-University of Alaska Fairbanks Cooperative Geochronology Laboratory.

${ }^{b}$ Constants used in age calculations: $\lambda_{\varepsilon}=0.581 \times 10^{-11} ; \lambda_{\beta}=4.962 \times 10^{-10} \mathrm{yr}^{-1}$; and ${ }^{40} \mathrm{~K} / \mathrm{K}_{\text {total }}=1.167 \times 10^{-4} \mathrm{~mol} / \mathrm{mol}$.

'Minimum age (sample does not meet petrographic criteria for a reliable date).

$\mathrm{rad}=$ radiogenic.

Table 4. Fossil information ${ }^{\mathrm{a}}$

\begin{tabular}{|c|c|c|c|c|c|c|c|}
\hline $\begin{array}{l}\text { Map } \\
\text { no. }\end{array}$ & $\begin{array}{l}\text { Rock } \\
\text { unit }\end{array}$ & Latitude & Longitude & $\begin{array}{c}\text { Specimen } \\
\text { no. }\end{array}$ & Fossil type & Age & Remarks \\
\hline 1 & $\mathrm{Kkm}$ & $61^{\circ} 26^{\prime} 12^{\prime \prime}$ & $157^{\circ} 32^{\prime} 55^{\prime \prime}$ & M8089 & Pelecypod Inoceramus sp. & Cretaceous(?) & \\
\hline 2 & $\mathrm{Kkm}$ & $61^{\circ} 21^{\prime} 12^{\prime \prime}$ & $157^{\circ} 40^{\prime} 40^{\prime \prime}$ & M8082 & Plant & Indeterminate & \\
\hline 3 & Kkh & $61^{\circ} 1753^{\prime \prime}$ & $157^{\circ} 53^{\prime} 19^{\prime \prime}$ & M8088 & Pelecypod Inoceramus sp. & Cretaceous(?) & Fragments only \\
\hline 4 & Kkh & $61^{\circ} 17^{\prime} 19^{\prime \prime}$ & $157^{\circ} 50^{\prime} 00^{\prime \prime}$ & M8085 & $\begin{array}{l}\text { Pelecypod Inoceramus sp. } \\
\text { Inoceramus hobetsensis }\end{array}$ & Late Cretaceous (Turonian) & \\
\hline 5 & $\mathrm{Kkm}$ & $61^{\circ} 16^{\prime} 30^{\prime \prime}$ & $157^{\circ} 57^{\prime} 18^{\prime \prime}$ & M8096 & $\begin{array}{l}\text { Pelecypod Inoceramus } \\
\text { tenuistraiatus }\end{array}$ & Late Cretaceous (Turonian) & \\
\hline 6 & Kkh & $61^{\circ} 16222^{\prime \prime}$ & $157^{\circ} 57^{\prime} 11^{\prime \prime}$ & M8094 & Pelecypod Inoceramus sp. & Cretaceous(?) & In deformed hornfels \\
\hline 7 & Kkh & $61^{\circ} 16^{\prime} 13^{\prime \prime}$ & $158^{\circ} 00^{\prime} 09^{\prime \prime}$ & M8083 & $\begin{array}{l}\text { Pelecypod Inoceramus sp. } \\
\text { Inoceramus hobetsensis }\end{array}$ & Cretaceous (Turonian?) & \\
\hline 8 & KJs & $61^{\circ} 17^{\prime} 27^{\prime \prime}$ & $158^{\circ} 11^{\prime} 45^{\prime \prime}$ & M8090 & Pelecypod Inoceramus sp. & Cretaceous(?) & Fragments only \\
\hline 9 & Kkt & $61^{\circ} 11^{\prime} 14^{\prime \prime}$ & $157^{\circ} 57^{\prime} 59^{\prime \prime}$ & M8093 & Pelecypod Inoceramus sp. & Cretaceous(?) & Cast of fragments \\
\hline
\end{tabular}

${ }^{2}$ Fossils identified by John W. Miller, U.S. Geological Survey, Menlo Park, California. Unpublished fossil report dated May 2, 1985.

${ }^{b}$ USGS Museum number. 